\title{
Takt Time Analysis in Lean Six Sigma: From Conventional to Integration
}

\author{
Tan Owee Kowang, Lim Kim Yew, Ong Choon Hee
}

\begin{abstract}
Lean Six Sigma offers a comprehensive roadmap, tools and technique for continuous business process improvement. Principally, Lean Six Sigma integrates Lean's principle of "value" and "speed" with Six Sigma's "consistency" (i.e. variation reduction) concept into the DMAIC (Design, Measure, Analyze, Improve, Control) framework. The integration of Lean and Six Sigma advances the pace of business process improvement. Conceptually, Lean and Six Sigma must be applied side by side from both management (i.e. soft practices) and technical (i.e. hard practices) perspectives. However, empirical research found that prior studies on Lean Six Sigma tends to focus on the study of integration from the soft perspective, such as exploring and confirming the determinants for Lean Six Sigma success as well as the application of Lean Six Sigma processes within varies business environments. There is lack of study on the integration of Lean Six Sigma from hard perspective. Hence, the concept of how Lean and Six Sigma tools could be integrated remains ambiguous because there are no standard guideline that available. As such, based on a Lean Six Sigma project(of minimizing new students registration cycle time)that conducted in one of local private university as single case study, this paper explores how Lean and Six Sigma tools could be integrated based on Lean Six Sigma principle, with the focus on a Lean's tool, namely "Takt Time Analysis". Finding from the study suggested that Takt Time Analysis could be expanded from "Lean-based" tools to as "Lean Six Sigma tool" by including process variation and process capability as parameters for analysis. The finding as well as the LSS based Takt Time Analysis methodology developed in this study has descriptive value in terms of studying the integration of Lean and Six Sigma tools that govern continuous business process improvement via Lean Six Sigma.
\end{abstract}

Index Terms: Lean Six Sigma, Takt Time, Hard Practices, Soft Practices

\section{INTRODUCTION}

Stiff competitive in marketplace compels business organizations to continuously explore the best methodology for business improvement. The traditional non-data driven improvement methodology, such as identifying improvement opportunity based on top management experiences is now inadequate to accomplish the business needs for improvement [1].Instead, data driven improvement

Revised Manuscript Received on December 30, 2019.

* Correspondence Author

Tan Owee Kowang*, Azaman Hashim International Business School, Universiti Teknologi Malaysia, Johor Bahru, Malaysia.

Lim Kim Yew, Faculty of Business, Communication \& Law, Inti International University, Nilai, Malaysia.

Ong Choon Hee, Azaman Hashim International Business School, Universiti Teknologi Malaysia, Kuala Lumpur, Malaysia.

(C) The Authors. Published by Blue Eyes Intelligence Engineering and Sciences Publication (BEIESP). This is an open access article under the CC BY-NC-ND license (http://creativecommons.org/licenses/by-nc-nd/4.0/) methodology such as Lean, Six Sigma and Lean Six Sigma are in favored because these improvement methodologies outline a systematic roadmap, analysis tools and technique for continuous business process improvement based on real data [2]. As such, business organizations could go beyond the traditional incremental improvement approach, and aims for radicalor break-through improvement.

\section{LEAN SIX SIGMA: AN INTEGRATION OR SUMMATION?}

\section{A. Lean Principle}

Holistically, Lean is an operation philosophy focuses on maximizing value of operational processes[3].Within the context of Lean, "Value" is viewed as the output of operational processes that fulfilled customer expectations, which subsequently driving customer satisfaction, promote customer loyalty and sustain business growth[4]. Lean principle categorizes operational processes into three categories, Value-added, Non Value-added and Operational Value-added processes [2]. An activity or process can be described as adding value to customers only when the "value" is recognized by the customers. While Non value-added refers to activity that takes time and/or resources that does not contribute to meeting customer requirements. Meantime, an activity can be "Operational" value-added if the activity is required to sustain the workplace ability to perform customer value-added activities, including requirements by contract or other laws and regulation [5]. The implementation of Lean involves the process of eliminating Non-value added activities, optimizing Operational value-added activities and maximizing value added activities, with the ultimate aim to speed up the process [5].

\section{B. Six Sigma Principle}

Six Sigma principle emphasizes on the consistency of process output toward meeting customers' expectation [6].From Six Sigma perspective, the consistency of a process could be assessed via the index that comparing process specification range versus process variation, or namely process capability index. Process specification is derived from customers' expectation or customer requirement, hence, the prime focus of Six Sigma principle is to minimize process output's variation. A six sigma process refers to a process with process capability index or Cpk that more than 1.5 [5].

The principle of Six Sigma is adopted in operational environment via two common data driven improvement frameworks, DMAIC (Design, Measure, Analyze, Improve, Control) or DMADV (Design, Measure, Analyze, Design, Verify) methodologies[7]. DMAIC is commonly applied for improvement of process or product that already exist, while DMADV is applicable for break-through improvement through the development of new product or process [7]. 


\section{C. "Lean Six Sigma" or "Lean + Six Sigma"}

The concept of blending Lean and Six Sigma principles began in late 90s [6]. Lean Six Sigma combines the lean principles of "value" and "speed" with the "consistency" Concept of Six Sigma into the DMAIC framework. Theoretically, the combination of Lean and Six Sigma promotes the fastest rate of improvement in customer satisfaction, process speed, cost, quality and invested capital [8].

Conceptually, Lean and Six Sigma must be applied side by side from both management (i.e. soft) and technical (i.e. hard) perspective, not as independent improvement or "first one then the other" approaches. Empirical research found that prior studies [1],[2],[3]on Lean Six Sigma tends to focus on the study of integration from the soft perspective, such as exploring and confirming the determinants for Lean Six Sigma success as well as the application of Lean Six Sigma processes within varies business entities, such as Supply Chain Management, Services and Research and Development [9]. There is lack of study on the integration from the hard perspective. Hence, the concept of how Lean and Six Sigma tools could be integrated remains ambiguous because there are no standard guideline that available.

Lean tools identified waste and eliminate non-value-added steps to approach six sigma quality much faster, while Six sigma tools recognizes the impact of variation and aims to bring the process under control [9], [10]. However, Lean Six Sigma tools are commonly viewed by prior studies as two independent sets of tools served for different purpose, one for Lean, the other for Six Sigma as shown in Fig. 1.

Hence, this paper advances the discussion in Lean Six Sigma by views Lean Six Sigma tools into three categories. On top of the traditional Lean tools and Six Sigma tools categories, the paper explore the potential integration of Lean and Six Sigma tools to form the third category, namely Lean Six Sigma tools as illustrated in Fig. 2

As such, based on a Lean Six Sigma project (of minimizing new students registration cycle time) that conducted in one of local private university as single case study, this paper explores how Lean and Six Sigma tools could be integrated based on Lean Six Sigma principle, with the focus on a Lean's tool, namely "Takt Time Analysis".

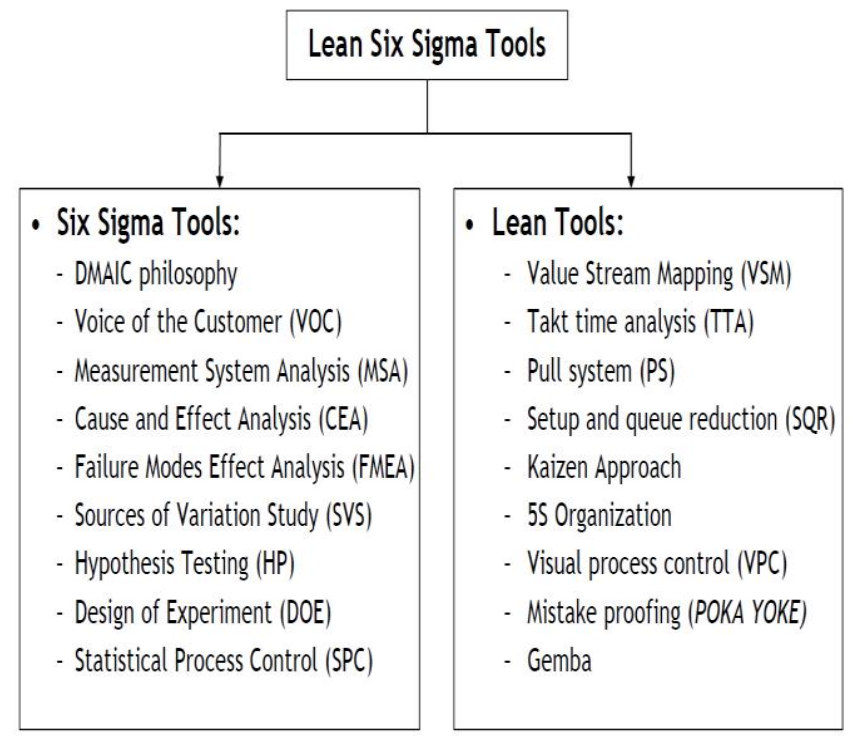

Fig. 1 Essential Lean and Six Sigma Tool

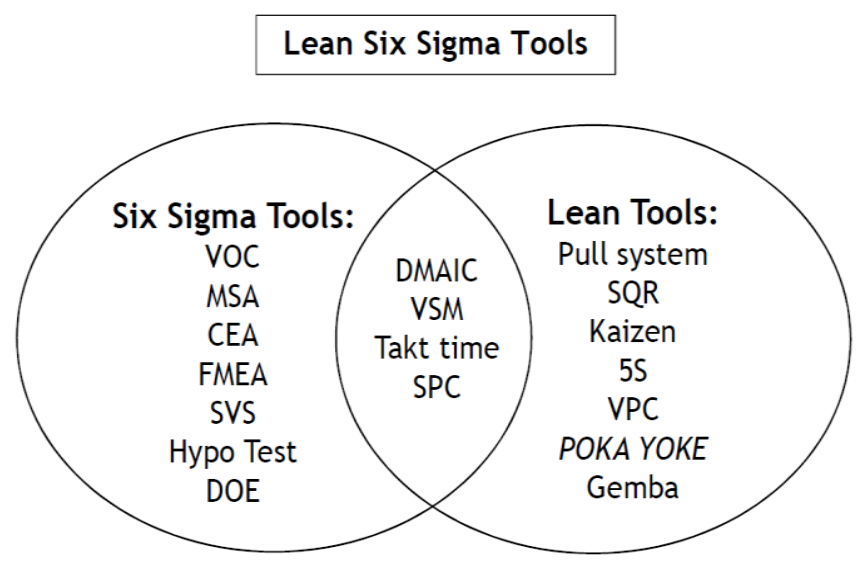

Fig. 2 New Perspective of Lean Six Sigma Tools Categorization

\section{CASE STUDY}

\section{A. Background and Objective}

Registration of new students is one of the most important process especially for private institutions. An efficient new students' registration process not only minimized the resources that required to support the registration process, but also left a good impression to the new students on the university's professionalism. Hence, the case study used in this paper is a Lean Six Sigma project in one of the private institutions in Malaysia to address students' feedback or Voice of Customer (VOC) in regard with the unsatisfactory of the lengthy new students' registration process.

\section{B. Define Phase: Critical to Quality}

The VOC data was subsequently organized and verified versus customer needs to establish the Critical Customer Requirements (CCR).

The current new students' registration process took approximately 2 and a half hour (150 minites) whiles students expected it should be completed within one and the half hour. As such the objective of the Lean Six Sigma project is to students' registration time by $50 \%$, with the targeted Critical to Quality (CTQ) of maximum 75 minutes or 1 hour 15 minutes from the point students submitted their registration documentation until students completed hostel registration.

\section{Define Phase: Process Mapping}

The detail of new students' registration process was developed via a series of Lean Six Sigma process mapping tools, which are SIPOC (Supplier, Input, Process, Output, Customer) diagram, Top-down chart and Functional Deployment Process Map. SIPOC was used to scope the project, Top-down chart details the higher level view of process, while Functional Deployment Process Map defines the departmental boundaries of the process.

Five processes were identified from the process mapping as the main steps for the current new students' registration process, which are: 
Process 1: Documents compilation and submission

Process 2: Main (Faculty/Academic) registration

Process 3: Registration and hostel fee payments

Process 4: Application of student pass

Process 5: Hostel registration

\section{Measure Phase}

The relationship between the project objective, or namely the output indicator of the Lean Six Sigma project (i.e. New students' registration cycle time) with the five processes identified from process mapping need to be established in order to identify and develop the process improvement plan [11].

As such, five indicators were developed(i.e. time taken for each process) for the five main processes identified in process mapping. Indicators for the five main processes represent the specific measures that evaluate the degree to which the inputs to a process (i.e. input indicator) as well as the effectiveness, efficiencies and quality of the processes (i.e. process indicators) affect the output indicator [12].

In conjunction with this, the cycle time for "Documents compilation and submission" process was labelled as input indicator, while cycle time for the rest for the four processes were defined as process indicators as shown in Fig. 3.

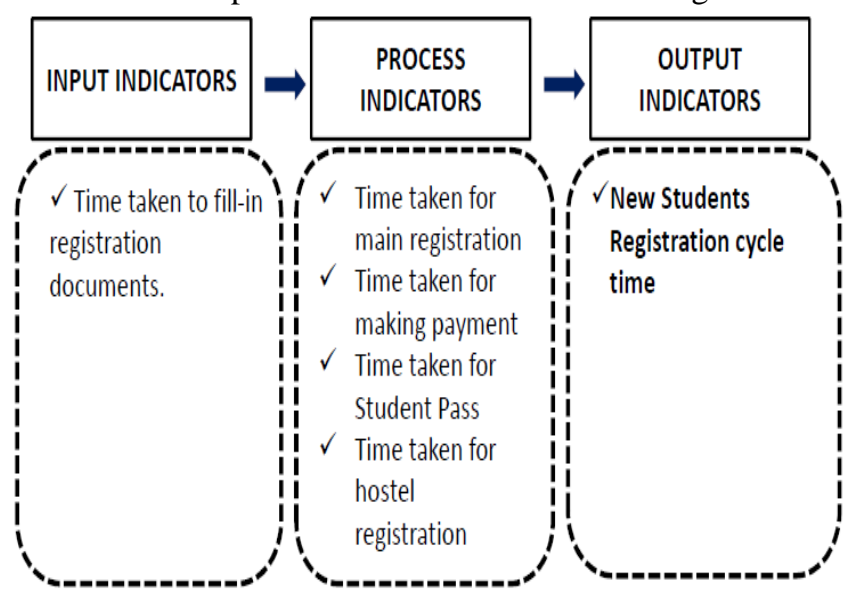

Fig. 3 IPO (Input-Process-Output) Indicators

Subsequently, a measurement plan for the 5 indicators was developed, and 30 data of cycle times (in minutes) were collected for each indicators. The mean measure of all indicators are summarized in Table 1.The targeted Critical to Quality (CTQ) for the Lean Six Sigma process is maximum 75 minutes. Due to there were 5 main processed involved in the new students registration process, hence, the CTQ for each process is 75/5 = 15 minutes.

Table. 1 Measurement result

\begin{tabular}{|c|l|c|}
\hline No & Indicator & $\begin{array}{c}\text { Mean Cycle } \\
\text { time (Minutes) }\end{array}$ \\
\hline 1 & $\begin{array}{l}\text { Time taken to fill-in registration } \\
\text { documents }\end{array}$ & 5.6 \\
\hline 2 & Time taken for main registration & 19.4 \\
\hline 3 & Time taken for making payment & 23.4 \\
\hline 4 & Time taken for Student Pass & 8.7 \\
\hline 5 & Time taken for hostel registration & 16.8 \\
\hline
\end{tabular}

As refers to Table 1, mean cycle time for two of processes (i.e. Time taken to fill-in registration documents and Time taken for student pass) are below the targeted process CTQ of 15 minutes, while cycle time for the other processes are above targeted process CTQ.

\section{E. Analysis Phase: Process Capability}

Process capability refers to the capability of a process to maintain process variability within a specified allowable tolerance width [12]. For the case study of the LSS project, the tolerance range is derived from the process CTQ, which is maximum 15 minutes. Process capability for the 5 processes were analyzed via Minitab. An example of capability analysis output for process 3 (Registration and hostel fee payment) is shown in Fig 4. The result of analysis shown that Cpk for process 3 is -0.28 .

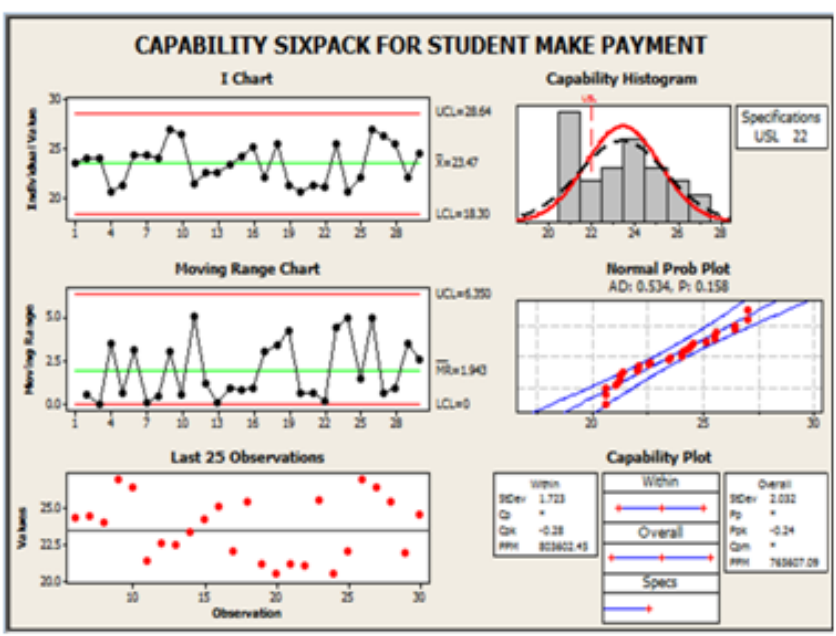

Fig. 4 Process Capability for Process 3

\section{F. Conventional Takt Time Chart}

Takt Rate refers to the amount of product or service required by customers over a continuous period of time, which is stated in units per time, while Takt Time refer to the inverse of takt rate when describing the output of a given step, which is stated in time per unit [10]. For the case under study, the Takt Time for the Lean Six Sigma project is maximum 15 minutes. Processes should be timed to produce at the takt time, any process that higher than takt time will be disappointing customers, while process that lower than takt time will be producing output that exceed customer demand Takt time chart is used as depiction way to illustrate where and time consumed in all processes versus targeted Takt time, which is easier to compare steps to each other but not visually emphasize wasted time as strongly as a time value map. Conventional Takt time chart for the Lean Six Sigma project under study is shown in Fig. 5. 
Takt Time Analysis in Lean Six Sigma: From Conventional to Integration

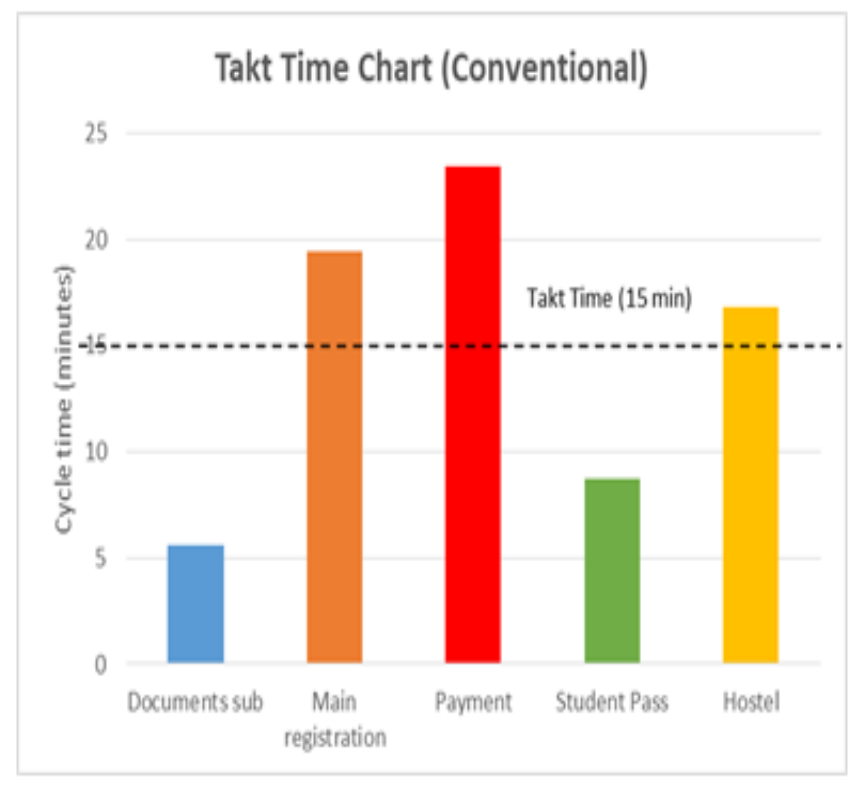

Fig. 5 Conventional Takt Time Chart

The conventional Takt time chart of Fig. 5 purely assesses mean process cycle time without takes into consideration the variation and process capability of each process. Bases on Fig. 5, three processes (i.e. Main registration; Payment and Hostel registration) were identified as over project takt time, or failed to meet customer expectation. While two processes (Fill-in documents and Student Pass application) were found below project Takt time which reflects processes are overdesigned or overstaffed.

Bases on the conventional Takt time chart, improvement opportunities identified by the project team were:

1. To combine "Fill-in documents" and "Student Pass" processes.

2. To reduce or eliminate Non value-added time, minimize Operational value-added time and optimize Value-added for Main registration; Payment and Hostel registration processes.

\section{G. Integrated Takt Time Chart}

Lean Six Sigma principle focuses on maximizing customers' value-added processes and minimizing processes' variation [2].However, the conventional Takt Time Chart focuses on analyzing mean processes' cycle time versus takt time without assessing the variation of cycle times. Hence, the conventional approach of takt time analysis does not accomplish the principle of Lean Six Sigma and fundamentally it is Lean based tool rather than Lean Six Sigma tools.

As such, the conventional Takt Time Chart need to be expanded to integrate both Lean and Six Sigma principle. Hence, on top of analyzing mean processes cycle times, process variation should also be incorporated into the analysis to form a Lean and Six Sigma integrated Takt Time Chart. The chart is developed by adding the variation of process cycle time to the conventional Takt Time Chart. The variation is representing by the maximum and minimum cycle time for each process as summarizes in Table 2 . Which is illustrated by a smaller bar in Fig. 6 .
Table. 2 Process Mean, Minimum and Maximum Cycle time

\begin{tabular}{|l|c|c|c|c|}
\cline { 2 - 4 } \multicolumn{1}{c|}{} & \multicolumn{3}{c|}{ Cycle Time (Minutes) } & \multicolumn{1}{c}{} \\
\hline Indicator & Mean & Min & Max & Cpk \\
\hline Fill-in documents & 5.9 & 4.5 & 9.0 & 0.32 \\
\hline Main registration & 21.4 & 12.0 & 25.0 & -0.33 \\
\hline Payment & 23.4 & 16.0 & 28.0 & -0.28 \\
\hline Student Pass & 10.7 & 8.4 & 16.1 & 0.55 \\
\hline Hostel & 16.2 & 12.0 & 18.0 & -0.47 \\
\hline
\end{tabular}

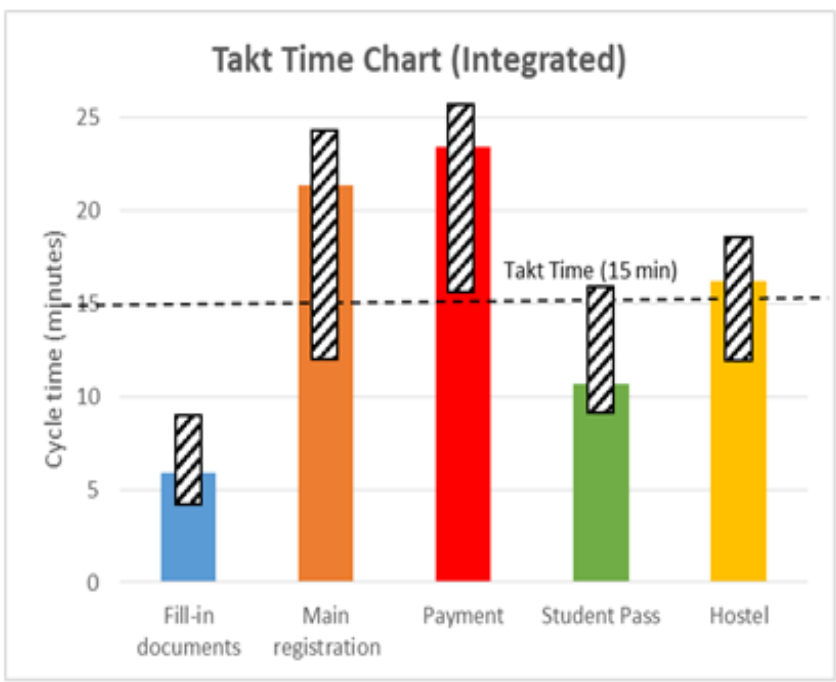

Fig. 6 Integrated Takt Time Chart

The interesting finding from Fig. 6 is "Application of student pass process" which was viewed as "overstaffed process" (i.e. cycle time below Takt Time) by conventional Takt Time Chart, however it is suggested by the Integrated Takt Time Chart as process that failed to meet customer expectation (i.e. cycle time above Takt Time) when process variation is integrated into analysis (i.e. the maximum cycle time (16.1 minutes) is higher than Takt time).In addition, from Table 2, process capability (Cpk) for "Fill in documents" and "Student Pass" processes are 0.32 and 0.55 respectively, which is lower than the targeted Six Sigma level of 1.5. As such the proposed action for both process is to improve Cpk for both processes to 1.5 prior to combination.

In addition, main registration and hostel registration were regarded as process that disappointing customers (process cycle time higher than Takt Time) in conventional Takt Time Chart. However, outcome from Integrated Takt Time Chart suggested that out of 30 customers under study, both processes are able to fulfill the targeted Takt Time of 15 minutes for "certain" customers but not all due to variation. As such, the proposed action for both processes is to study the source of variation, i.e. the difference between the max and min cycle time. Theoretically, source of variation could be narrowed down to temporal variation (i.e. variation over time such as morning and afternoon), man to man variation (variation among operators) or variation on method used. 
Table 3 summarizes the comparison of improvement actions proposed by both conventional and integrated Takt Time Chart (TTC). Apparently, the improvement opportunities spotted from the Integrated Takt Time Chart are different from the Conventional Takt Time Chart, whereby the actions identified from integrated approach tends to address the improvement opportunities from Lean Six Sigma approach.

Table. 3 Comparison between Conventional and Integrated Takt Time Chart (TTC)

\begin{tabular}{|c|l|l|l|}
\hline No & Process & $\begin{array}{l}\text { Action from } \\
\text { Conventional TTC }\end{array}$ & $\begin{array}{l}\text { Action from Integrated } \\
\text { TTC }\end{array}$ \\
\hline 1 & $\begin{array}{l}\text { Documents } \\
\text { submission }\end{array}$ & Combines with process 4 & $\begin{array}{l}\text { Improve Cpk to > 1.5 } \\
\text { before combine with } \\
\text { process 4 }\end{array}$ \\
\hline 2 & $\begin{array}{l}\text { Main } \\
\text { registration }\end{array}$ & $\begin{array}{l}\text { Reduce/eliminates NVA } \\
\text { time, minimize OVA time } \\
\text { and optimize VA time. }\end{array}$ & $\begin{array}{l}\text { Study Source of Variation } \\
\text { prior to value analysis and } \\
\text { Cpk improvement }\end{array}$ \\
\hline 3 & Fee payment & $\begin{array}{l}\text { Reduce/eliminates NVA } \\
\text { time, minimize OVA time } \\
\text { and optimize VA time. }\end{array}$ & $\begin{array}{l}\text { Reduce/eliminates NVA } \\
\text { time, minimize OVA time } \\
\text { and optimize VA time. }\end{array}$ \\
\hline 4 & Student pass & $\begin{array}{l}\text { Combines with process 1 } \\
\text { Improve Cpk to > 1.5 } \\
\text { before combine with } \\
\text { process 1 }\end{array}$ \\
\hline 5 & $\begin{array}{l}\text { Hostel } \\
\text { registration }\end{array}$ & $\begin{array}{l}\text { Reduce/eliminates NVA } \\
\text { time, minimize OVA time } \\
\text { and optimize VA time. }\end{array}$ & $\begin{array}{l}\text { Study Source of Variation } \\
\text { prior to value analysis and } \\
\text { Cpk improvement }\end{array}$ \\
\hline
\end{tabular}

\section{CONCLUSION}

This paper explores how Lean and Six Sigma tools could be integrated based on Lean Six Sigma principle, with the focus on a Lean's tool, namely "Takt Time Analysis". Finding from the study suggested that Takt Time Analysis could be expanded from "Lean-based" tools to as "Lean Six Sigma tool" by including process variation and process capability as parameters for analysis. The finding as well as the LSS based Takt Time Analysis methodology developed in this study has descriptive value in terms of studying the integration of Lean and Six Sigma tools that govern continuous business process improvement via Lean Six Sigma.

\section{ACKNOWLEDGMENT}

Authors wish to acknowledge the Malaysian Ministry of Education and Universiti Teknologi Malaysia under the Research Grant (Vote No. 18H59) for sponsoring this publication.

\section{REFERENCES}

1. A.J. Ali, M.A. Islam, and L.P. Howe, L. P. "A study of sustainability of continuous improvement in the manufacturing industries in Malaysia: Organizational self-assessment as a mediator. Management of Environmental Quality,":An International Journal Vol. 24(3), pp. 408-426. 2013.

2. V. Frank, H. James, M. Chuck, and C. Rich, C. The Lean Six Sigma Black Belt Handbook. Broken Sound Parkway NW: CRC Press, Taylor \& Francis Group, 2014
3. S.M. Vijaya. "Corporate perspectives: commonalities and differences between Six Sigma and Lean,”.International Journal of Lean Six Sigma, Vol. 6(3), pp. 281-288. 2015.

4. J. Sisson and A. Elshennawy, "Achieving success with Lean," International Journal of Lean Six Sigma, Vol. 6(3), pp. 263-280. 2015.

5. T.O. Kowang, L.K. Yew, O.C. Hee, G.C. and C.S Long, "Lean Six Sigma, Implementation: Does Success Means Sustainability?' International Journal of Academic Research in Business and Social Sciences, Vol. 9(6), pp. 907-914. 2019

6. D. Pacheco, L. Pergher, G.L.R. Vaccaro, C.F. Jung, C. F. and C. Ten Caten. "18 comparative aspects between Lean and Six Sigma," International Journal of Lean Six Sigma, Vol. 6(2), pp. 161-175. 2015.

7. O.K. Tan, S.Y. Tan, R. Amran and S.L. Choi Sang Long, "Lean Six Sigma Sustainability Framework: A Case Study on an Automotive Company," Asian Journal of Scientific Research, Vol. 9: 279-283.2016.

8. G. Yadav and T.N. Desai. "Lean Six Sigma: a categorized review of the literature," International Journal of Lean Six Sigma, Vol. 7(1), 2-24. 2016.

9. M.H. Nabila, O.K. Tan and C.H. Goh. "Categorization of Lean Research and Development Tools and Techniques: A process-Based Approach," Indian Journal of Science and Technology, Vol 10(3), pp.1-3.

10. M.S. Raisinghani, H. Ette, R. Pierce, G. Cannon, and P. Daripaly. "Six Sigma: concepts, tools, and applications," Industrial Management \& Data Systems, Vol. 105(4), pp. 491-505, 2005.

11. I. Gremyr and J, Fouquet. "Design for Six Sigma and lean product development,".International Journal of Lean Six Sigma, Vol. 3(1), pp. 45-58. 2012.

12. M. Assarlind, I. Gremyr and K. Bäckman. "Multi-faceted views on a Lean Six Sigma application," International Journal of Quality \& Reliability Management, Vol. 30(4), pp. 387-402. 2013.

\section{AUTHORS PROFILE}

Tan Owee Kowang, Azaman Hashim International Business School, Universiti Teknologi Malaysia, Johor Bahru, Malaysia

Lim Kim Yew, Faculty of Business, Communication \& Law, Inti International University, Nilai, Malaysia

Ong Choon Hee, Azaman Hashim International Business School, Universiti Teknologi Malaysia, Kuala Lumpur, Malaysia 